\title{
GENDER DIFFERENCES IN ACHIEVEMENT MOTIVATION OF EMPLOYED ADULTS
}

\author{
Valentina Ružić \\ Centre for Education and Research, Naklada Slap \\ Miramarska cesta 105, 10000 Zagreb \\ valentina@nakladaslap.com \\ Krunoslav Matešić, ml. \\ Department of Psychology, Catholic University of Croatia \\ Ilica 242, 10000 Zagreb \\ krunoslav.matesic@unicath.hr \\ Antonia Štefanec \\ Centre for Education and Research, Naklada Slap \\ Miramarska cesta 105, 10000 Zagreb \\ antonia@nakladaslap.com
}

\begin{abstract}
Achievement motivation is a concept that can be used for the explanation of individual differences in achievement and success in various contexts as well as an explanation of motivated behaviour. Despite the fact that a generally accepted definition of achievement motivation is still lacking because of disagreement over the traits it encompasses, numerous studies have been conducted on this subject. Researchers agree that achievement motivation is an important factor in professional life, particularly in achieving high professional success when external demands for focusing activity on achieving goals are minimal. It is of particular importance for those activities that have low structure levels and high autonomy.

The study included 267 employed adults (124 males and 143 females) older than 18 years. Participants completed the Achievement Motivation Inventory (AMI) which consists of 17 achievement motivation scales. Individual scales form three clusters of motivational facets relating to self-assurance, ambition and self-control.

The aim of the study was to determine the existence of gender differences in individual achievement motivation dimensions in employed adults in the Republic of Croatia. The results show the existence of significant gender differences in achievement motivation facets related to self-assurance and ambition in favour of males (e.g. confidence in success, dominance, and fearlessness) and self-control in favour of females. These results are in agreement with previous research and contribute to the usefulness of multifaceted measures of achievement motivation.
\end{abstract}

Key words: achievement motivation, gender differences, AMI 


\section{INTRODUCTION}

Achievement motivation is a concept that can be used for the explanation of individual differences in achievement and success in various contexts such as the school, sport or work environment (Kanfer, 1990). It is also used to explain motivated behaviour, which is the reason why researchers have focused on studying various aspects and applications of this construct. Despite numerous studies of achievement motivation (e.g. Cassidy and Lynn, 1989; Weiner and Kukla, 1970; Atkinson and Litwin, 1966) there is no generally accepted definition of achievement motivation. The reason is disagreement over the components it encompasses and the method of measurement of the construct.

Studies of differences in needs or motives of the individuals began early in the 20th century. The pioneer, responsible for introducing the concept of achievement motivation, was Henry Murray $(1938,1971)$ who defined the concept as "ambition which is evident in action" (1971, p. 9). The need for achievement (nAch) is defined as the need „to accomplish something difficult. To master, manipulate or organize physical objects, human beings, or ideas. To do this as rapidly, and as independently as possible. To overcome obstacles and attain a high standard. To excel one's self. To rival and surpass others. To increase self-regard by the successful exercise of talent" (Murray, 1938., p. 164). This definition reveals a certain degree of activity, including an individual's spirit of competition which is present in later conceptualizations of achievement motivation (e.g. McClelland, 1985) and carried over to the present day.

The first inclusive definition of achievement motivation is attributed to McClelland, Atkinson, Clark and Lowell (1976) who describes a relatively stable predisposition of the individual representing an important achievement factor. McClelland (1955) has suggested the differentiation of intrinsic and extrinsic motivation where achievement motivation is part of the intrinsic motivational system. With regard to more recent definitions, notable is the one put forth by Clark, Varadarajan and Pride (1994) where achievement motivation is a multidimensional concept defined as a competition with standards of success or the strivings of an individual in setting and achieving personal goals.

Despite differences in opinion on what this concept includes, the importance of achievement motivation in professional life is indisputable, particularly in those professions where individuals are not obliged to direct their activities toward achievement as a final goal (Schuler, Thornton, Frintrup and Mueller-Hanson, 2004). More to the point, importance of achievement motivation is greater in achieving high professional success when external demands for activities aimed at achieving goals are minimal. Those are professions with a low level of structure and a high level of autonomy.

According to Ward (1997), individuals with high achievement motivation are energetic workers focused on job, competitive, concentrated on increasing success, focused on goals, possess managerial potential and are proactive. 
Whichever dimensions we think should be included in this construct, gender differences in those dimensions are of interest. Findings on gender differences in achievement motivation have changed over time. Studies conducted during the 1950 's and 1960's (e.g. Veroff, Depner, Kukla and Douvan, 1980) have shown lower achievement motivation in women in relation to men, which is in accordance with the fact that women were primarily homemakers, not present in the workforce. Studies conducted from the late 1960's and onwards (e.g. Jenkins, 1987) have shown an increase in achievement motivation in women, which is attributed to the effects of emancipation. According to Hyde and Kling (2001) this increase was most probably caused by increased educational and work opportunities for women. Greene and DeBacker (2004) have shown that men and women in the 1960's differed in that men were focused on long-term goals and planning and women on altruistic behaviour.

Studies from the 1980's and 1990's (Eccles, 1984) revealed findings such as stereotypically higher expectations of boys in mathematics and sport and of girls in languages and arts. More recent studies, such as that of Greene and DeBacker (2004), show that males set fewer goals than females, but those goals are higher.

Studies of these changes and differences in the distribution and expression of achievement motivation in men and women have inspired the study of these differences in the Republic of Croatia. Thus, the aim of this research is to examine the existence of gender differences in individual dimensions of achievement motivation based on the Achievement Motivation Inventory (AMI; Schuler, Thornton III, Frintrup and Mueller-Hanson, 2004) in employed adults in the Republic of Croatia.

\section{METHOD}

\section{Subjects}

The study encompassed 267 employed adults (124 males and 143 females) aged between 18 and $63(M=37.73)$. The participants were employed in organizations throughout the Republic of Croatia and testing was conducted by psychologists employed in these companies. All participants signed informed consent forms.

\section{Instruments}

The instrument used in this study was the Achievement Motivation Inventory (AMI; Schuler et al., 2004; Croatian editor Željko Jerneić). It is based on the concept of achievement motivation as a personality trait and developed on the concept of the 
relationship between various facets of achievement motivation, which are similar to traditional aspects of personality.

The inventory consists of 170 items on a seven degree Likert scale ranging from $1=$ not at all related to me to $7=$ completely related to me. Items form 17 scales that can be grouped in three clusters. The first cluster consists of following scales: Fearlessness, Flexibility, Confidence in Success, Preference for Difficult Tasks, Independence and Dominance. This cluster is named Self-Assurance and it represents a striving for success without fear of failure on difficult tasks. The second cluster consists of scales Goal Setting, Eagerness to Learn, Competitiveness, Compensatory Effect, Engagement, Pride in Productivity, Status Orientation and "Flow". This factor is named Ambition and represents a general tendency toward motivation in competitive situations. The third cluster, named Self-Control consists of Internality, Persistence and Self-Control and can be best described as a tendency toward persisting with the project or task even in situations where obstacles need to be overcome.

The AMI scales show internal consistency measured by the Cronbach alpha coefficient ranging from .64 to .85 . Intercorrelations between scales show a moderate relationship between individual motivation achievement facets with the mean intercorrelation of .35 .

\section{PROCEDURE}

Psychologists employed in organizations in Republic of Croatia administered inventory individually explaining the aim of the research to every participants in order to get their written consent. Administration of inventory lasted, on average, 25 minutes. The entire procedure was conducted in accordance with the Standards for Educational and Psychological Testing (AERA, APA, NCME, 2005).

\section{RESULTS AND DISCUSSION}

In order to analyze the gender differences in achievement motivation in working adults in the Republic of Croatia, basic descriptors were calculated for all the scales that form earlier explained three clusters of scales (Table 1). Normality of distributions of each scale was tested using the Kolmogorov-Smirnov test and only an Internality scale showed a slight deviation from the normal distribution (K-S = $1.52 ; p=.03$; skewness $=-.35$, kurtosis $=-.27$ ). Giving that, analysis of variance was used to test gender differences in results for individual scales (Table 1) and for scale clusters and total AMI score (Table 2).

Results for these scale clusters and total result of the AMI, including the statistical significance of gender differences are presented in Table 2 . 
Table 1. Means, standard deviations, significance of gender differences and Cohen's d for results obtained on the 17 scales of the AMI divided in three clusters

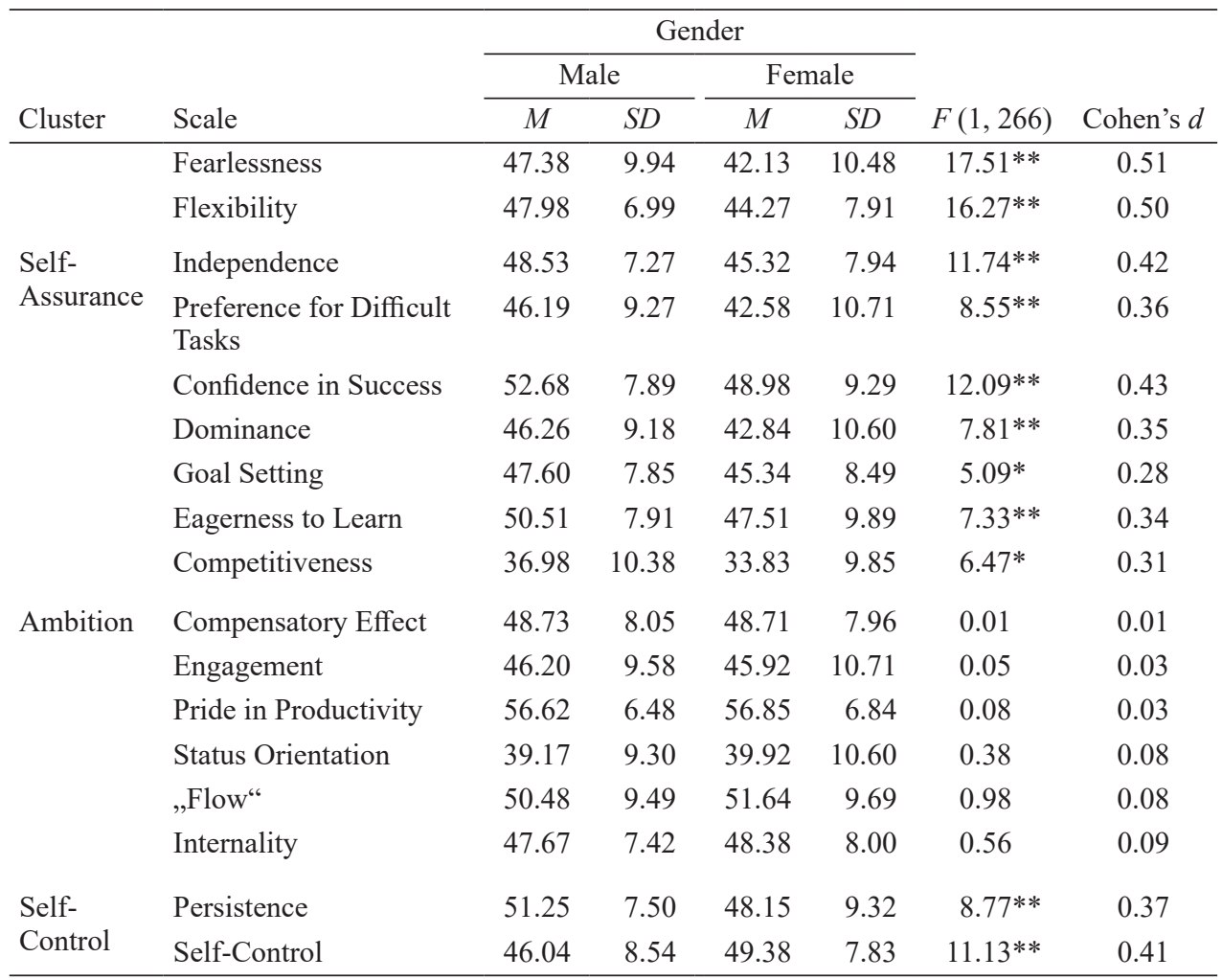

Note: ${ }^{*} p<0.05 ; * p<0.01$.

Table 2. Means, standard deviations and significance of gender differences for results on scale clusters and the total AMI score

\begin{tabular}{|c|c|c|c|c|c|c|}
\hline \multirow[b]{3}{*}{ AMI } & \multicolumn{4}{|c|}{ Gender } & \multirow[b]{3}{*}{$F(1,266)$} & \multirow[b]{3}{*}{ Cohen's $d$} \\
\hline & \multicolumn{2}{|c|}{ Male } & \multicolumn{2}{|c|}{ Female } & & \\
\hline & $M$ & $S D$ & $M$ & $S D$ & & \\
\hline Self-Assurance & 289.02 & 37.10 & 266.12 & 44.34 & $20.59 * *$ & 0.56 \\
\hline Ambition & 376.29 & 44.78 & 369.71 & 54.71 & 1.13 & 0.13 \\
\hline Self-Control & 144.96 & 18.21 & 145.92 & 20.46 & 0.16 & 0.05 \\
\hline AMI total score & 810.27 & 80.10 & 781.75 & 105.20 & $6.07 *$ & 0.31 \\
\hline
\end{tabular}

Analysis of results in clusters show that all scales in the Self-Assurance cluster reveal significant gender differences in favour of males, with small to medium ef- 
fect sizes (calculated as Cohen's $d$ ). This is also the case in some scales forming the Ambition cluster (Goal Setting, Eagerness to Learn, Competitiveness). Other scales in the Ambition cluster did not show significant differences.

People achieving high results on the Self-Assurance dimensions are not afraid of failure, embrace changes, enjoy new, challenging tasks, and are confident in their success even in the face of obstacles. The Ambition dimension can be described as a wish to achieve importance and status among colleagues and a feeling of success due to a job well done. People achieving high results on this dimension are motivated by the prospect of professional advancement and the knowledge that they are more successful than their colleagues. These people are happiest when they are perceived as people who invest their maximum in the job (Schuler et al., 2004). These dimensions are traditionally linked to males and their role as dominant, ambitious and fearless men, so higher results are expected for these dimensions.

On the other hand, the Self-Control cluster has yielded significant differences in favour of women for the Persistence and Self-Control scales, while the Internality scale did not show such a difference. Self-Control can be described as the ability and willingness to invest vast efforts and delay gratification until the set goal is achieved. People achieving high results on this dimension believe that success or failure are due to internal causes, not situational variables, and will therefore be disciplined, organized and persistent in achieving their goals (Schuler et al., 2004).

When looking at results on clusters, Self-Assurance cluster scale revealed a significant difference in favour of males, as well as the total AMI score, while the other two clusters did not show statistically significant gender differences.

The results obtained in this study are in accordance with findings of studies using this instrument in other countries (e.g. Pašková, 2007; Schuler et al, 2004; Schuler and Prochaska, 2000) and with the traditional conception of gender roles, i.e. men as self-confident, ambitious and dominant. The achieved gender differences in AMI scales, primarily those scales comprising the Self-Assurance and Ambition clusters are in accordance with the stereotypical view of gender roles where boys are encouraged from an early age to engage in competition while girls are encouraged to cooperate and avoid competitive situations (Sutter and Glätzle-Rützler, 2015). Different studies have shown that men react more strongly to situations of comparison with others, while women tend to avoid competitive situations (Datta Gupta, Poulsen and Villeval, 2005; Booth and Nolen, 2009; Croson and Gneezy, 2009; Dohmen and Falk, 2011). Our results concur with these findings, showing that men achieved higher results on facets dealing with competition, fearlessness and independence, while women achieved higher results on self-control dimensions.

In line with studies showing changes in achievement motivation depending on age (e.g. Sutter and Glätzle-Rützler, 2015) and education (e.g. Riepe, 2004), further investigation of differences in facets of achievement motivation is needed, including the relationship between achievement motivation and specific types of occupation. 


\section{CONCLUSION}

The importance of achievement motivation has been recognized in achieving professional success when external demands for focusing on attaining goals are minimal. The results of this study using the AMI in the Republic of Croatia are in accordance with those in other countries (e. e. Pašková, 2007; Schuler et al., 2004), thus confirming the stability of the achievement motivation concept presented in the AMI inventory.

The gender differences seen for the scales, clusters and total AMI scores, primarily referring to higher results for males in the Self-Assurance and Ambition domains, are in accordance with stereotypical gender roles where boys are encouraged to compete, while girls are encouraged to cooperate and avoid competitive situations (Sutter and Glätzle-Rützler, 2015). Different studies show that men react more strongly to situations of comparison with others while women lean toward avoiding competitive situations. Although effect sizes calculated as Cohen's $d$ are small to medium, our results are in accordance with these findings, showing that males achieve higher scores for facets connected with competition, fearlessness and independence, while women achieve higher scores for self-control.

\section{REFERENCES}

AERA, APA, \& NCME (2005). Standardi za pedagoško i psihološko testiranje [Standards for Educational and Psychological Testing]. Jastrebarsko: Naklada Slap.

Atkinson, J. W., \& Litwin, G. H. (1966). Achievement motive and test anxiety conceived as motive to approach success and motive to avoid failure. In J. W. Atkinson, \& N. T. Feather (Eds.), A theory of achievement motivation (pp. 75-91). New York: John Wiley $\&$ Sons, Inc.

Booth, A. L., \& Nolen, P. J. (2009). Choosing to Compete: How Different are Girls and Boys? Journal of Economic Behavior \& Organization, 81(2), 542-555. doi:10.1016/j. jebo.2011.07.018

Cassidy, T., \& Lynn, R. (1989). A multifactorial approach to achievement motivation: The development of a comprehensive measure. Journal of Occupational and Applied Psychology, 12, 301-311.

Clark, T., Varadarajan, P. R., \& Pride, W. M. (1994). Environmental management: The construct and research propositions. Journal of Business Research, 29, 23-38. doi:10.1016/0148-2963(94)90024-8

Croson, R., \& Gneezy, U. (2009). Gender Differences in Preferences. Journal of Economic Literature, 47, 448-474. doi:10.1257/jel.47.2.448

Datta Gupta, N., Poulsen, A., \& Villeval, M. C. (2005). Male and Female Competitive Behavior: Experimental Evidence. IZA Discussion Paper, 1833. doi: 10.2139/ssrn.851227

Dohmen, F., \& Falk, A. (2011). Performance Pay and Multidimensional Sorting: Productivity, Preferences and Gender. American Economic Review, 101, 556-590. doi: 10.1257/ aer.101.2.556 
Eccles, J. S. (1984). Sex differences in achievement patterns. In T. Sonderegger (Ed.), Nebraska Symposium on Motivation (pp. 97-132). Lincoln: University of Nebraska Press.

Greene, B. A., \& DeBacker, T. K. (2004). Gender and orientations toward the future: Links to motivation. Education Psychology Review, 16, 91-120. doi: 10.1023/B:EDPR.0000026608.50611.b4

Hyde, J. S., \& Kling, K. C. (2001). Women, Motivation, and Achievement. Psychology of Women Quarterly, 25, 364-378. doi: 10.1111/1471-6402.00035

Jenkins, S. R. (1987). Need for achievement and women's careers over 14 years. Evidence for occupational structural effects. Journal of Personality and Social Psychology, 53, 922-932. doi: 10.1037/0022-3514.53.5.922

Kanfer, R. (1990). Motivation theory and industrial and organizational psychology. In M. D. Dunnette, \& L. M. Hough (Eds.), Handbook of industrial and organizational psychology, (pp. 76-170). Palo Alto, CA: Consulting Psychology Press.

McClelland, D. C. (1955). Measuring motivation in fantasy: The achievement motive. In D. C. McClelland (Ed.), Studies in motivation (pp. 401-413). New York: AppletonCentury-Crofts, Inc.

McClelland, D. C. (1985). Human motivation. Glenview, IL: Scott, Foresman \& Co.

McClelland, D. C., Atkinson, J. W., Clark, R. A., \& Lowell, E. L. (1976). The achievement motive. New York: Halsted Press.

Murray, H. A. (1938). Explorations in personality. New York: Oxford University Press.

Murray, H. A. (1971). The Thematic Apperception Test manual. Los Angeles: Western Psychological Services.

Pašková, L. (2007). Gender differences in achievement motivation. The new educational review, 13, 245-252.

Riepe, S. M. (2004). Effects of educational level and gender on achievement motivation. PSI CHI Journal of Undergraduate Research, 9, 33-38.

Schuler, H., \& Prochaska, M. (2000). Das Leistungsmotivationsinventar (LMI). Handanweisung [The Achievement Motivation Inventory (LMI). Instructions]. Göttingen: Hogrefe.

Schuler, H., Thornton, G., Frintrup, A., \& Mueller-Hanson, R. (2004). AMI Achievement Motivation Inventory. Technical and User's Manual. Göttingen: Hogrefe.

Sutter, M., \& Glätzle-Rützler, D. (2015). Gender differences in the willingness to compete emerge early in life and persist. Management Science, 61, 2339 - 23354. doi: 10.1287/ mnsc. 2014.1981

Veroff, J., Depner, C., Kukla, A., \& Douvan, E. (1980). Comparison of American motives: 1957 versus 1976. Journal of Personality and Social Psychology, 39, 1249-1262. doi: $10.1037 / \mathrm{h} 0077729$

Ward, E. (1997). Multidimensionality of Achievement Motivation among Employed Adults. The Journal of Social Psychology, 137, 542-544. doi: 10.1080/00224549709595476

Weiner, B., \& Kukla, A. (1970). An attributional analysis of achievement motivation. Journal of Personality and Social Psychology, 15, 1-20. doi: 10.1037/h0029211 


\title{
SPOLNE RAZLIKE U MOTIVACIJI ZA POSTIGNUĆE KOD ODRASLIH ZAPOSLENIH OSOBA
}

\begin{abstract}
Sažetak
Motivacija za postignuće je koncept koji se koristi za objašnjenje individualnih razlika u uspješnosti u različitim kontekstima te kao objašnjenje motiviranog ponašanja. Iako još uvijek nema općeprihvaćene definicije motivacije za postignuće i postoji neslaganje oko toga koje komponente ona obuhvaća, provedena su mnogobrojna istraživanja na ovu temu. Ono u čemu se istraživači slažu jest da je motivacija za postignuće važna u profesionalnom životu, a posebno dobiva na važnosti u ostvarivanju visokog profesionalnog uspjeha kad su vanjski zahtjevi za usmjeravanje aktivnosti na postizanje ciljeva minimalni. Dakle, naročito je važna u zanimanjima koja karakterizira nizak stupanj strukturiranosti i visok stupanj autonomije.

U istraživanju je sudjelovalo 267 zaposlenih osoba (124 M i 143 Ž) starijih od 18 godina. Sudionici su ispunjavali Inventar motivacije za postignuće (Achievement Motivation Inventory, AMI) koji obuhvaća 17 ljestvica motivacije za postignuće. Ljestvice formiraju tri klastera motivacijskih faceta koji se odnose na samouvjerenost, ambiciju i samokontrolu.

Cilj istraživanja je ispitati postojanje razlika prema spolu u pojedinim dimenzijama motivacije za postignuće kod zaposlenih odraslih osoba u Republici Hrvatskoj. Rezultati su pokazali da s obzirom na spol, postoje značajne razlike u facetama motivacije za postignuće vezanim uz samouvjerenost i ambiciju, u korist muškaraca (npr. uvjerenost u uspjeh, dominantnost, neustrašivost), te u samokontroli u korist žena. Ovakvi rezultati su u skladu s dosadašnjim istraživanjima i govore u prilog korisnosti multifacetne mjere komponenata motivacije za postignuće.
\end{abstract}

Ključne riječi: motivacija za postignuće, spolne/rodne razlike, AMI

Prihvaćeno za tisak: 07. 09. 2016. 
